\title{
PEMANFAATAN BUAH PINUS DENGAN SERBUK GERGAJI KAYU JATI MENJADI BRIKET SEBAGAI ENERGI ALTERNATIF
}

\author{
Joko Setiyo Wibowo ${ }^{1 *}$, Wegie Ruslan ${ }^{1}$ \\ ${ }^{1}$ Jurusan Teknik Mesin, Universitas Pancasila, Indonesia, 12640
}

\begin{abstract}
ABSTRAK
Briket merupakan energi alternatif yang terbuat dari arang serta ditambahkan perekat sehingga menyatu dengan bentuk dan ukuran tertentu. Bahan baku pembuatan briket yaitu buah pinus dan serbuk gergaji kayu jati dengan variasi komposisi yaitu briket A 10\% arang buah pinus dan $90 \%$ arang serbuk gergaji kayu jati, briket B 30\% dan 70\%, briket C 50\% dan 50\%, briket D 70\% dan 30\%, briket E $90 \%$ dan 10\%. Sedangkan komposisi perekat yaitu tepung tapioca dan air dengan perbandingan 1:10 untuk masing-masing variasi komposisi. Berdasarkan hasil pengujian rata-rata nilai kalor briket diperoleh briket $\mathrm{A}=5515 \mathrm{kal} / \mathrm{g}$, briket $\mathrm{B}=5571 \mathrm{kal} / \mathrm{g}$, briket $\mathrm{C}=5604$ $\mathrm{kal} / \mathrm{g}$, briket $\mathrm{D}=5651 \mathrm{kal} / \mathrm{g}$, briket $\mathrm{E}=5642 \mathrm{kal} / \mathrm{g}$. Rata-rata nilai kalor yang terendah dan tertinggi adalah briket A memiliki rata-rata nilai kalor terendah sebesar $5515 \mathrm{kal} / \mathrm{g}$ dan Briket D memiliki rata-rata nilai kalor tertinggi sebesar $5651 \mathrm{kal} / \mathrm{g}$. Rata-rata nilai kalor briket secara keseluruhan dikategorikan memenuhi syarat mutu briket mengacu SNI Briket Arang Kayu 01-6235-2000. Perbandingan nilai kalor briket dengan batubara mengacu SNI Klarifikasi Sumber Daya dan Cadangan Batubara 13-6011-1999 bahwa briket dari perpaduan buah pinus dengan serbuk gergaji kayu jati dapat dikatergorikan kelas batubara energi rendah.
\end{abstract}

Kata kunci : briket; energi alternatif; sampah organik.

\begin{abstract}
Briquettes are an alternative energy that is made from charcoal and added with adhesive so that it blends with a certain shape and size. The raw materials for making briquettes are pines and teak powder with various compositions, namely briquette A $10 \%$ pine charcoal and $90 \%$ teak sawdust charcoal, briquettes B $30 \%$ and $70 \%$, briquettes C $50 \%$ and $50 \%$, briquettes D $70 \%$ and $30 \%$, E briquettes $90 \%$ and 10\%. Meanwhile, the adhesive composition was tapioca flour and water with a ratio of 1:10 for each variation in the composition. Based on the test results the average calorific value of briquettes obtained briquettes $A=5515 \mathrm{cal} / \mathrm{g}$, briquettes $B=5571 \mathrm{cal} / \mathrm{g}$, briquettes $C=5604 \mathrm{cal} / \mathrm{g}$, briquettes $D$ $=5651 \mathrm{cal} / \mathrm{g}$, and briquette $E=5642 \mathrm{cal} / \mathrm{g}$. The lowest and highest average heating value is briquette $A$ which has the lowest average value of $5515 \mathrm{cal} / \mathrm{g}$ and Briquette D has the highest average calorific value of $5651 \mathrm{cal} / \mathrm{g}$. The average calorific value of briquettes as a whole is categorized as meeting the quality requirements of briquettes according to SNI for Wood Charcoal Briquettes 01-6235-2000. Comparison of the calorific value of briquettes with coal refers to SNI Clarification of Coal Resources and Reserves 13-6011-1999 that briquettes from a combination of pines with teak powder can be categorized as low energy grade coal.
\end{abstract}

Keywords : alternative energy; briquettee ; organic waste;

\section{PENDAHULUAN}

Pada tahun 2015, energi fosil menyumbang sebesar $93,7 \%$ dan sisanya $6,2 \%$ dipenuhi dari Energi Baru Terbarukan (EBT). Jumlah persentase dari energi fosil yaitu minyak bumi sebesar $43,0 \%$, gas bumi $22,0 \%$, dan batubara 28,7\% (Direktorat Jenderal EBTKE, 2016).

Meningkatnya kebutuhan energi fosil mengakibatkan ketidakseimbangan antara laju

\footnotetext{
* Penulis korespondensi

Email: jokosetiyowibowo@gmail.com
}

Diterima 06 Juli 2021; Penerimaan hasil revisi 22 Juli 2021; Disetujui 23 Agustus 2021

Tersedia online September 2021

AME (Aplikasi Mekanika dan Energi): Jurnal Ilmiah Teknik Mesin @ 2021 
penggunaan energi fosil dalam menentukan cadangan energi baru, energi fosil semakin lama menipis karena di explorasi secara terus-menerus.

Menghadapi tantangan krisisnya energi, pemerintah sudah menyiapkan perpres No.5 tahun 2006 tentang kebijakan energi nasional dan target kebijakan energi nasional di tahun 2025 yaitu menekan kebutuhan energi fosil dapat digantikan dengan Energi Baru Terbarukan (EBT) dan pemerintah sudah menyetujui kebijakan energi nasional dengan mengacu kepada PP.No.79 tahun 2014 bahwa di tahun 2025 Energi Baru Terbarukan ditargetkan sebesar 23\% (Direktorat Jenderal EBTKE, 2017).

Indonesia mempunyai pontensi Energi Baru Terbarukan (EBT) yang sangat besar dalam mengatasi kelangkaan sumber daya energi. Menurut Kepala Bagian Komunikasi dan Layanan Informasi Biro KLIK Kementrian ESDM bahwa Indonesia memiliki sumber daya EBT sebesar $400 \mathrm{GW}$ dan baru dimanfaatkan sebesar $1 \mathrm{GW}$, termasuk dalam pemanfaatan biomassa sebagai pengganti batubara dapat berpontensi sebesar $50 \mathrm{GW}$. Murujuk dari data Kementrian ESDM dan program pengembangan EBT tentang Kebijakan Energi Nasional yaitu penambahan kapasitas pembangkit listrik dengan bahan bakar biomassa sebesar 180 MW pada tahun 2020. Sehingga pemerintah mendorong adanya suatu upaya integrasi dalam mengembangkan dan meningkatkan penelitian tentang pemanfaatan limbah dari industri, kehutanan, dan pertanian untuk dimanfaatkan sebagai energi alternatif (Anam and Majid, 2020).

Beberapa sumber energi alternatif yang ramah lingkungan, lebih murah, dan dapat diperbaharui yaitu biomassa yang berupa pemanfaataan bahan organik menjadi bahan bakar padat yang dikenal dengan nama briket dan energi ini sangatlah cocok dikembangkan di Indonesia.

Briket adalah bahan bakar padat yang terbuat dari arang serta ditambahkan perekat sehingga dapat menyatu dengan bentuk dan ukuran tertentu. Arang merupakan bahan baku briket dari hasil proses pirolisis berupa bahan-bahan organik yang dihasilkan melalui proses fotosintesis, baik berupa produk maupun buangan. Bahan perekat arang dapat dari beberapa bahan anorganik maupun organik. Pemilihan bahan perekat harus berdasarkan pada daya adhesi yang baik ketika perekat dicampur dengan arang sesuai Peraturan Menteri Energi dan Sumber Daya Mineral
Republik Indonesia No.47 Tahun 2006 (Herjunata, Noviandini, and Kholisoh, 2020).

Pemanfaatan energi fosil yaitu batubara sebagian besar digunakan Pembangkit Listrik Tenaga Uap (PLTU) dan bidang industri lainnya untuk mencukupi kebutuhan energi bahan bakar (Setiawan, Wibowo, and Rosyid, 2020). Pembangkit Listrik Tenaga Uap (PLTU) merupakan salah satu pembangkit listrik yang memasok sebagian besar energi listrik ke konsumennya dan dirasa efektif untuk mencukupi tingkat kebutuhan terhadap energi listrik, namun PLTU ini tidak tergolong sebagai pembangkit listrik yang ramah lingkungan (Bono, Wahyono, and Burhani, 2017).

Sampah merupakan persoalan yang harus kita dihadapi dan tanggung jawab kita bersama yang harus dikelola supaya dapat bermanfaat kembali seperti menjadikan sampah daur ulang, dimanfaatkan kembali, dan digunakan kembali (Parta and Karmiadji, 2017). Buah Pinus merupakan limbah atau sampah dari hutan pinus yang mudah ditemukan dan melimpah karena belum dimanfaatkan. Sehingga buah pinus dapat diharapkan menjadi solusi dalam mengurangi limbah organik dengan cara diolah menjadi bahan bakar padat sebagai energi alternatif dan mengurangi beban pencermaran limbah didalam hutan. Kayu Jati merupakan kayu yang sering digunakan sebagai bahan baku pembuatan furniture (Wicaksono and Wijayanto, 2018). Ketersediaan limbah kayu jati yaitu serbuk kayu jati cukuplah banyak, pemanfaatan limbah kayu jati banyak dimanfaatkan sebagai bahan untuk membantu proses pembakaran batu bata dan dibuang begitu saja, sehingga limbah serbuk gergaji kayu jati dapat mencemari lingkungan disekitarnya (Mursalim et al., 2019).

Pembuatan briket bahan baku yang digunakan adalah memanfaatkan limbah hutan pinus yaitu buah pinus dan limbah kayu jati yaitu serbuk gergaji kayu jati. Dari dua bahan baku tersebut akan digunakan sebagai bahan baku pembuatan briket sebagai energi alternatif pengganti batubara, karena bahan bakar batubara merupakan sumber daya energi yang tidak dapat diperbarui, tergolong tidak ramah lingkungan dan jumlahnya sangatlah terbatas.

Tujuan yang bisa didapat dalam pembuatan briket yaitu mendapatkan nilai kalor briket dari perpaduan buah pinus dengan serbuk gergaji kayu jati dan membandingkan nilai kalor dengan jenis batubara. 


\section{METODE PENELITIAN}

Pengujian briket dilaksanakan di Laboratorium CSL (Collaborative STEM Laboratories) Universitas Prasetiya Mulya, Tangerang. Metode yang digunakan dalam pengujian Nilai Kalor Briket menggunakan metode internal laboratorium CSL, Universitas Prasetiya Mulya dengan alat bom kalorimeter otomatis IKA ${ }^{\circledR}$ C6000. Metode pengujian kadar air dan kadar abu menggunakan metode SNI Briket Arang Kayu 01-6235-2000 (SNI, 2000).

Indonesia memiliki kualitas briket yang diizinkan dengan berdasarkan Standar Nasional Indonesia (SNI). Berikut ini kualitas standar briket yang diizinkan SNI Briket Arang Kayu 016235-2000 sebagai berikut:

Tabel 1. Persyaratan mutu briket (SNI, 2000)

\begin{tabular}{cccc}
\hline No & $\begin{array}{c}\text { Jenis } \\
\text { Uji }\end{array}$ & Satuan & Persyaratan \\
\hline 1 & $\begin{array}{l}\text { Kadar } \\
\text { air }\end{array}$ & $\%$ & Maksimum 8 \\
& $\begin{array}{l}\text { Kadar } \\
\text { abu }\end{array}$ & $\%$ & Maksimum 8 \\
& $\begin{array}{l}\text { Nilai } \\
\text { kalor }\end{array}$ & kal/g & $\begin{array}{c}\text { Minimum } \\
5000\end{array}$ \\
\hline
\end{tabular}

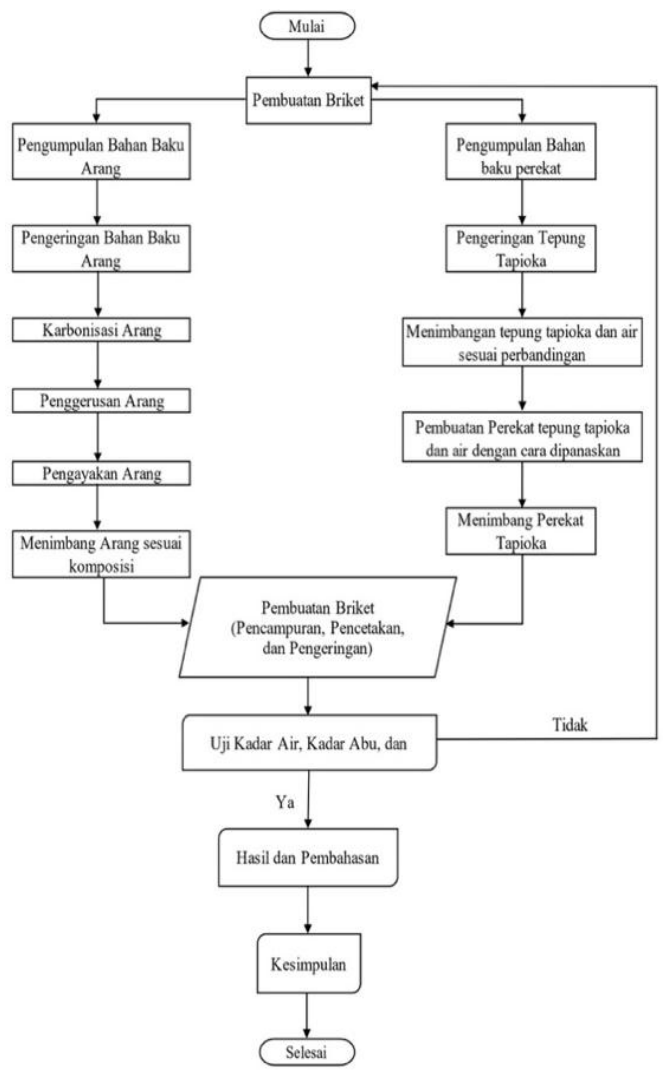

Gambar 1. Diagram alir pembuatan briket
Berikut ini komposisi briket dari perpaduan buah pinus dan serbuk gergaji kayu jati serta ditambahkan perekat tapioka dapat dilihat pada tabel 2 sebagai berikut:

Tabel 2. Komposisi briket

\begin{tabular}{cccc}
\hline Variasi & $\begin{array}{c}\text { Arang } \\
\text { Briket } \\
\text { Pinus }\end{array}$ & $\begin{array}{c}\text { Arang } \\
\text { Serbuk } \\
\text { Gergaji } \\
\text { Kayu Jati }\end{array}$ & $\begin{array}{c}\text { Rasio } \\
\text { Perbandingan } \\
\text { Perekat Tapioka }\end{array}$ \\
\hline A & $10 \%$ & $90 \%$ & Tepung tapioka \\
B & $30 \%$ & $70 \%$ & dan air 1:10 \\
C & $50 \%$ & $50 \%$ & (Perekat \\
D & $70 \%$ & $30 \%$ & dicampur \\
E & $90 \%$ & $10 \%$ & dengan merata) \\
\hline
\end{tabular}

\subsection{Pembuatan Briket}

\section{2..1.1. Alat}

1. Alat pelindung diri

2. Tampah

3. Kayu bakar

4. Alat pengarangan

5. Stopwatch

6. Themocoupel

7. Lumpang kayu

8. Saringan ukuran 60 mesh

9. Timbangan digital dan kantong plastik

10.Panci

11. Wadah dan pengaduk perekat 12.Alat cetak briket dan papan kayu 13.Mistar baja

\section{2..1.2.Bahan}

1. Buah pinus

2. Serbuk gergaji kayu jati

3. Perekat dari tepung tapioka dan larutan air

\section{2..1.3.Langkah Kerja Pembuatan Briket}

1. Limbah padat buah pinus dan serbuk gergaji kayu jati diambil dari tempat pembuangan limbah.

2. Buah pinus, serbuk gergaji kayu jati, dan tepung tapioka dikeringkan dengan panas sinar matahari selama tiga hari dengan suhu cuaca $\pm 30^{\circ} \mathrm{C}$.

3. Kemudian dilakukan proses pengarangan. Suhu pengarangan 102 $-256{ }^{\circ} \mathrm{C}$ selama 2 jam. Dalam proses 
pengarangan diharapkan terjadi pengarangan yang sempurna.

4. Setelah proses pengarangan selesai kemudian tumbuk secara halus dan di ayak menggunakan saringan dengan ukuran 60 mesh.

5. Setelah selesai pengayakan kemudian pencampuran arang dari buah pinus dan serbuk gergaji kayu jati serta ditambahkan bahan perekat tapioka hingga tercampur merata.

6. Selanjutnya proses pencetakan menjadi briket dengan cara pemadatan menggunakan alat cetakan manual menggunakan tekanan beban $9 \mathrm{~kg}$ selama 30 detik.

7. Setelah selesai pencetakan keluarkan briket dari alat cetakan manual, untuk masing-masing briket diberi tanda/kode briket sesuai dengan variasi yang telah ditentukan.

8. Keringkan briket basah tersebut maksimal seminggu dengan panas sinar matahari untuk menghilangkan air yang terkandung didalam briket.

9. Kemudian timbang briket yang sudah dikeringkan untuk mengetahui bobot bersihnya.

10.Setelah briket ditimbang selanjutnya adalah proses pemeriksaan uji kadar air, kadar abu, dan nilai kalor dilaboratorium.

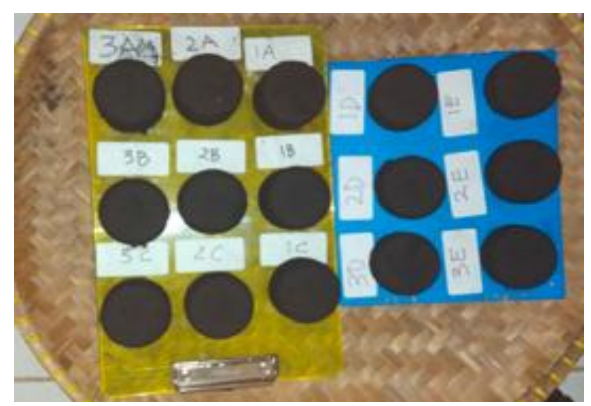

Gambar 2. Hasil pengeringan briket

\section{HASIL DAN PEMBAHASAN}

\subsection{Uji Kadar Air}

Penentuan kadar air mengikuti SNI Briket Arang Kayu 01-6235-2000. Berikut hasil uji kadar air dapat dilihat pada tabel 3 sebagai berikut:
Tabel 3. Uji kadar air

\begin{tabular}{cccccc}
\hline Pengujian & \multicolumn{5}{c}{ Variasi Komposisi Briket (\%) } \\
\hline Briket & A & B & C & D & E \\
P1 & 7,27 & 6,78 & 6,60 & 7,15 & 6,84 \\
P2 & 7,33 & 7,37 & 7,11 & 7,05 & 6,62 \\
P3 & 7,55 & 7,01 & 6,97 & 7,12 & 7,18 \\
Rata-rata & 7,38 & 7,05 & 6,89 & 7,10 & 6,88 \\
\hline
\end{tabular}

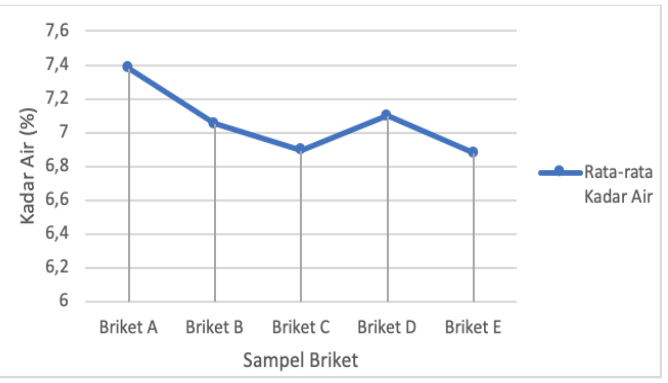

Gambar 3. Grafik rata-rata uji kadar air

Berdasarkan gambar 3 Grafik dari hasil uji kadar air briket rata-rata kadar air terendah dan tertinggi yaitu briket $\mathrm{C}$ memiliki rata-rata kadar air terendah sebesar 6,89\% dan briket A memiliki rata-rata kadar air tertinggi sebesar 7,38 \% .

Dari keseluruhan hasil rata-rata kadar air mengacu standar SNI Briket Arang Kayu 016235-2000 dapat dikategorikan lolos spesifikasi persyaratan mutu briket, dimana persyaratan mutu briket maksimum kadar air adalah $8 \%$.

\subsection{Uji Kadar Abu}

Penentuan kadar abu mengikuti SNI Briket Arang Kayu 01-6235-2000. Berikut hasil uji kadar abu dapat dilihat pada tabel 4 sebagai berikut:

Tabel 4. Uji kadar abu

\begin{tabular}{cccccc}
\hline Pengujian & \multicolumn{5}{c}{ ariasi Komposisi Briket (\%) } \\
\hline Briket & A & B & C & D & E \\
\hline P1 & 7,29 & 6,59 & 7,12 & 7,53 & 8,52 \\
P2 & 6,25 & 6,57 & 7,27 & 7,70 & 8,26 \\
P3 & 5,54 & 6,64 & 7,07 & 7,62 & 8,56 \\
Rata-rata & 6,36 & 6,60 & 7,15 & 7,61 & 8,44 \\
\hline
\end{tabular}




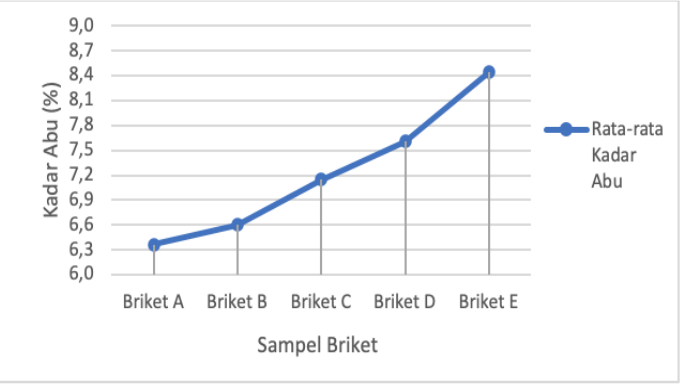

Gambar 4. Grafik rata-rata uji kadar abu

Berdasarkan gambar 4 Grafik dari hasil pengujian kadar abu rata-rata kadar abu terendah dan tertinggi yaitu briket A memiliki rata-rata kadar abu terendah sebesar $6,36 \%$ dan briket $\mathrm{E}$ memiliki rata-rata kadar abu tertinggi sebesar $8,44 \%$.

Dari keseluruhan hasil rata-rata kadar abu briket dapat dikategorikan lolos sesuai SNI Briket Arang Kayu 01-6235-2000 yaitu spesifikasi persyaratan mutu briket maksimum kadar abu sebesar 8\%. Rata-rata kadar abu yang lolos sesuai SNI Briket Arang Kayu 01-6235-2000 dalam pengujian ini adalah briket A sebesar $6,36 \%$, briket B sebesar 6,60 \%, briket C sebesar 7,15\%, dan briket D sebesar 7,61 \%. Sedangkan rata-rata kadar abu briket $\mathrm{E}$ dapat dikategorikan tidak lolos persyaratan mutu briket karena kadar abu briket E yang diperoleh adalah $8,44 \%$.

Faktor yang mempengaruhi briket E yaitu dapat dilihat dari grafik briket A sampai briket $\mathrm{E}$ grafiknya semakin naik, maka faktor pengaruhi kadar abu tinggi adalah massa jenis buah pinus lebih tinggi daripada serbuk gergaji kayu jati sesuai komposisinya briket $\mathrm{E}$ dengan perbandingan $90 \%$ buah pinus dan $10 \%$ serbuk gergaji kayu jati.

\subsection{Uji Nilai Kalor}

Penentuan nilai kalor mengikuti metode internal laboratorium CSL, Universitas Prasetiya Mulya. Alat penentuan nilai kalor menggunakan bom kalorimeter IKA® C 6000. Berikut hasil pengujian nilai kalor dapat dilihat pada tabel 5 sebagai berikut:
Tabel 5. Hasil uji nilai kalor

\begin{tabular}{cccccc}
\hline Pengujian & \multicolumn{5}{c}{ Variasi Komposisi Briket (kal/g) } \\
\hline Briket & A & B & C & D & E \\
P1 & 5584 & 5600 & 5618 & 5655 & 5711 \\
P2 & 5481 & 5583 & 5595 & 5695 & 5607 \\
P3 & 5478 & 5531 & 5600 & 5603 & 5609 \\
Rata-rata & 5515 & 5571 & 5604 & 5651 & 5642 \\
\hline
\end{tabular}

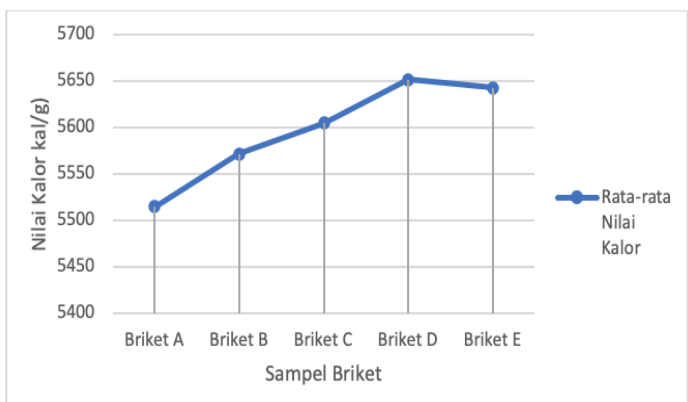

Gambar 5. Grafik rata-rata uji nilai kalor

Berdasarkan gambar 5. Grafik dari pengujian nilai kalor briket rata-rata nilai kalor terendah dan tertinggi yaitu briket A memiliki nilai kalor terendah sebesar $5515 \mathrm{kal} / \mathrm{g}$, dan nilai kalor briket $\mathrm{D}$ memiliki nilai kalor tertinggi sebesar $5651 \mathrm{kal} / \mathrm{g}$.

Briket $C$ dalam uji kadar air dan kadar abu ternyata hasil briket $\mathrm{C}$ terendah daripada briket $\mathrm{D}$, tetapi nilai kalor briket $\mathrm{C}$ juga tidak setinggi seperti briket $\mathrm{D}$ dengan kadar air 7,10 \%, kadar abu $7,61 \%$, dan rata-rata nilai kalornya tertinggi daripada briket $C$ yaitu sebesar $5651 \mathrm{kal} / \mathrm{g}$. Faktor yang mempengarui briket $\mathrm{C}$ dan briket $\mathrm{D}$ adalah perbedaan komposisi briket. Perbandingan kompoisi briket $\mathrm{C}$ yaitu arang buah pinus 50\% dan arang serbuk gergaji kayu jati 50\% sedangkan perbandingan komposisi briket D yaitu arang buah pinus $70 \%$ dan arang serbuk gergaji kayu jati $30 \%$. Faktor yang mempengaruhi komposisi yang paling dominan di dalam campuran yang dapat menaikan nilai kalor adalah arang buah pinus karena massa jenisnya lebih tinggi daripada arang serbuk gergaji kayu jati, namun dari briket C dan briket D mengacu kepada SNI Briket Arang Kayu 01-6235-2000 dapat dikategorikan lolos spesifikasi persyaratan mutu briket, dimana SNI Briket Arang Kayu 01-6235-2000 persyaratan mutu briket maksimum kadar air $8 \%$, maksimum kadar abu $8 \%$, dan minimum nilai kalor briket adalah $5000 \mathrm{kal} / \mathrm{g}$. Hasil penelitian 
dari uji proksimat dan nilai kalor parameter yang paling penting adalah nilai kalor karena semakin tinggi nilai kalor briket maka semakin baik pula kualitas briket yang dihasilkan, namun kualitas briket lebih baik harus lolos spesifikasi mengacu SNI Briket Arang Kayu 01-6235-2000.

\subsection{Perbandingan Nilai Kalor Briket dengan Jenis Batubara}

Penentuan nilai kalor briket dari campuran buah pinus dengan serbuk gergaji kayu jati dibandingkan dengan jenis batubara mengacu kepada SNI Klarifikasi Sumber Daya dan Cadangan Batubara 13-6011-1999. berikut ini nilai kalor briket dan jenis batubara dapat dilihat pada tabel 6 sebagai berikut:

Tabel 6. Perbandingan nilai kalor briket dengan jenis batubara

\begin{tabular}{ccccccc}
\hline \multicolumn{3}{c}{ Rata-rata Nilai Kalor Briket } & \multicolumn{2}{c}{ Nilai Kalor } \\
Barubara $(\mathrm{kal} / \mathrm{g})$
\end{tabular}

(*) Sumber: (SNI, 1999)

Berdasarkan Tabel 6 rata-rata nilai kalor briket yang dihasilkan yaitu briket A: $5515 \mathrm{kal} / \mathrm{g}$, briket B sebesar $5571 \mathrm{kal} / \mathrm{g}$, briket C sebesar 5604 $\mathrm{kal} / \mathrm{g}$, briket D sebesar $5651 \mathrm{kal} / \mathrm{g}$, dan briket E sebesar 5642 kal/g. Sedangkan standar nilai kalor batubara mengacu kepada SNI Klarifikasi Sumber Daya dan Cadangan Batubara 13-60111999 (SNI 1999), batubara dibagi manjadi dua jenis yaitu batubara energi rendah dan batubara energi tinggi. Batubara energi rendah memiliki nilai kalor sebesar kurang dari $7000 \mathrm{kal} / \mathrm{g}$ sedangkan batubara energi tinggi memiliki nilai kalor sebesar lebih dari $7000 \mathrm{kal} / \mathrm{g}$. Maka dapat disimpulkan bahwa briket dari campuran buah pinus dengan serbuk gergaji kayu jati dapat dikategorikan lebih rendah dari nilai kalor batubara dan hanya setingkat dengan nilai batubara yang rendah dan grafik tingkatan nilai kalor briket dengan batubara dapat dilihat pada gambar 6.

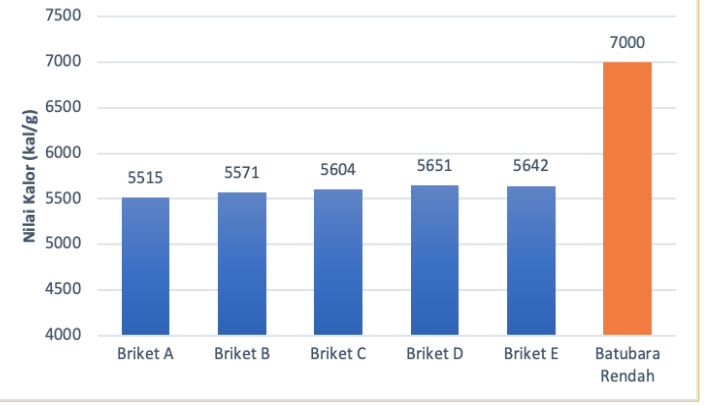

Gambar 6. Grafik perbandingan nilai kalor briket dengan jenis batubara

\section{KESIMPULAN}

Ternyata hasil penelitian dapat diperoleh briket A rata-rata nilai kalornya sebesar 5515 $\mathrm{kal} / \mathrm{g}$ dengan kadar air 7,38 \% dan kadar abu 6,36 $\%$, briket B rata-rata nilai kalornya sebesar 5571 $\mathrm{kal} / \mathrm{g}$ dengan kadar air 7,05\% dan kadar abu 6,60 $\%$, briket C rata-rata nilai kalornya sebesar 5604 $\mathrm{kal} / \mathrm{g}$ dengan kadar air 6,89\% dan kadar abu 7,15 $\%$, briket D rata-rata nilai kalornya $5651 \mathrm{kal} / \mathrm{g}$ dengan kadar air 7,10 \% dan kadar abu 7,61\%, briket E rata-rata nilai kalornya sebesar 5642 $\mathrm{kal} / \mathrm{g}$ dengan kadar air 6,88 \% dan kadar abu 8,44 $\%$. Briket yang lolos spesifikasi SNI Briket Arang Kayu 01-6235-2000 yaitu briket A, briket B, briket $\mathrm{C}$, dan briket $\mathrm{D}$. Sedangkan briket E tidak lolos spesifikasi karena kadar abu briket $\mathrm{E}$ diperoleh sebesar 8,44\%.

Perbandingan nilai kalor briket mengacu kepada SNI Klarifikasi Sumber Daya dan Cadangan Batubara 13-6011-1999, dapat disimpulkan bahwa briket A sebesar $5515 \mathrm{kal} / \mathrm{g}$, briket B sebesar $5571 \mathrm{kal} / \mathrm{g}$, briket C sebesar 5604 $\mathrm{kal} / \mathrm{g}$, briket D sebesar $5651 \mathrm{kal} / \mathrm{g}$, dan briket E sebesar $5642 \mathrm{kal} / \mathrm{g}$ dapat dikategorikan hasil penelitian diperoleh bahwa nilai kalor briket yang diteliti lebih rendah dari nilai kalor batubara dan hanya setingkat dengan nilai batubara yang rendah.

\section{REFERENSI}

Anam, Asroful, and Muhammad Azizul Majid. 2020. "Karakteristik Limbah Daun Tebu Sebagai Sumber Energi Baru Terbarukan Berbasis Densification Method." Jurnal Rekayasa Mesin 15 (1): 59-65.

Bono, Wahyono, and Muhammad S Burhani. 2017. "Analisis Konsumsi Batubara 
Spesifik Ditinjau Dari Nilai Kalor Batubara Dan Perubahan Beban Di PLTU Tanjung Jati B Unit 2." EKSERGI Jurnal Teknik Energi 13 (2): 50-53.

Direktorat Jenderal EBTKE. 2016. Statistik EBTKE 2016. Jakarta.

Direktorat Jenderal EBTKE. 2017. "Laporan Kinerja Semester 1-Tahun 2017." Jakarta.

Herjunata, Ricky, Shafira Ratna Noviandini, and Siti Diyar Kholisoh. 2020. "Pengaruh Variasi Perekat Pada Briket Berbahan Limbah Tempurung Kelapa." Seminar Nasional Teknik Kimia "Kejuangan” 11 (J): $1-5$.

Mursalim, Munir, Fitriani, and Intan Dwi Novieta. 2019. "Kandungan Selulosa, Hemiselulosa Dan Lignin Serbuk Gergaji Kayu Jati (Tectona Grandits L.F) Dan Daun Murbei (Morus Alba) Yang Dikombinasikan Sebagai Pakan Ternak." Seminar Nasional Sinergitas Multidisiplin Ilmu Pengetahuan Dan Teknologi 2: 323327.

Parta, and Djoko W. Karmiadji. 2017. "Analisis Desain Digester Pada Pengolahan Sampah Untuk Bahan Bakar Rumah Tangga." Teknobiz 7 (3): 150-155.

Setiawan, Arif, Aryo Wibowo, and Fadhila Rosyid. 2020. "Analisis Pengaruh Ekspor Dan Konsumsi Batubara Terhadap Pertumbuhan Ekonomi Indonesia." Jurnal Teknologi Mineral Dan Batubara 16 (2): 109-124.

SNI. 1999. "SNI 13-6011-1999 Klasifikasi Sumber Daya Dan Cadangan Batubara.'Jakarta.

SNI. 2000. "SNI 01-6235-2000 Briket Arang Kayu."Jakarta.

Wicaksono, Dimas, and Dwi Wahyu Wijayanto. 2018. "Mengolah Limbah Kayu Jati Menjadi Elemen Dekoratif." Seminar Nasional Kolaborasi Pengabdian Pada Masyarakat 1: 476-482. 